Pak. j. sci. ind. res. Ser. B: biol. sci. 201457 (3) 123-128

\title{
Enhanced Amylase Production by Fusarium solani in Solid State Fermentation
}

\author{
Yasser Bakri*, Mohammed Jawhar and Mohammed Imad Eddin Arabi \\ Department of Molecular Biology and Biotechnology, AECS, PO Box 6091, Damascus, Syria
}

(received January 29, 2014; revised May 7, 2014; accepted July 15, 2014)

\begin{abstract}
The present study illustrates the investigation carried out on the production of amylase by Fusarium species under solid state fermentation. All the tested Fusarium species were capable of producing amylase. A selected $F$. solani isolate SY7, showed the highest amylase production in solid state fermentation. Different substrates were screened for enzyme production. Among the several agronomic wastes, wheat bran supported the highest yield of amylase (141.18 U/g of dry substrate) after 3 days of incubation. Optimisation of the physical parameters revealed the optimum $\mathrm{pH}$, temperature and moisture level for amylase production by the isolate as $8.0,25{ }^{\circ} \mathrm{C}$ and $70 \%$, respectively. The above results indicate that the production of amylase by $F$. solani isolate SY7 could be improved by a further optimisation of the medium and culture conditions.
\end{abstract}

Keywords: agro-industrial wastes, $\alpha$-amylase, Fusarium spp., solid state fermentation

\section{Introduction}

$\alpha$-amylase (EC 3.2.1.1, a-1,4-glucan-4-glucanohydrolase), is an extra cellular enzyme, which catalyses the endocleavage of the a-1,4-glycoside linkages and the release of short oligosaccharides and a-limit dextrin. This enzyme is used commercially for the production of sugar syrups from starch, which consist of glucose, maltose, and higher oligosaccharides (Reddy et al., 2003). It is also extensively used in starch of liquefaction and paper, food, pharmaceutical and sugar industries. Although, amylases can be obtained from several sources, such as plants and animals, the enzymes from microbial sources generally meet industrial demand (Nwagu and Okolo, 2011; Pandey et al., 2001).

Fungal amylases are preferred to plant enzymes due to their short growth period, higher productivity and thermostability (Mishra et al., 2008). However, fungal growth and amylase production are dependent on growth conditions, such as type and concentration of carbon and nitrogen sources, metal ion requirement, $\mathrm{pH}$ and temperature of growth (Ghasemi et al., 2010; Cherry et al., 2004). Though many microorganisms can grow on a wide range of carbon and nitrogen sources, it is economically more viable to utilise the cheap and easily available resources as substrates for amylase production (de Castro and Sato, 2013; Pandey et al., 2001). Industrial enzymatic hydrolysis is influenced by a number of factors amongst which are environmental conditions of

\footnotetext{
*Author for correspondence; E-mail: ascientific@aec.org.sy
}

$\mathrm{pH}$, temperature and presence of metal ion (Riaz et al., 2007).

Fungal amylase is preferred for use in formulation for human or animal consumption involving application under acidic condition and around $37^{\circ} \mathrm{C}$. Studies on fungal amylase especially in the developing countries have concentrated mainly on filamentous fungi probably because of the ubiquitous nature and non-fastidious nutritional requirements of these organisms (Padmini et al., 2012; Guimaraes et al., 2006).

Fusarium is a large genus of filamentous fungi, and most of Fusarium species are harmless saprobes and relatively abundant members of the soil microbial community (Alazem, 2007; Summerell et al., 2001; Onyika et al., 1993). These species have the ability to produce different enzymes under fermentation conditions (Kikot et al., 2010; Pekkarinen et al., 2000). Cereal grains showed cavities and furrows in endosperm of starch granules, evidencing damage caused by amylases (Jackowiak et al., 2002). This ecological habitat of the fungus, however, implies that Fusarium would be a useful resource of extracellular enzymes. Solid state fermentation (SSF) is widely established for the production of enzymes from filamentous fungi (Zaferanloo et al., 2014; de Castro and Sato, 2013). Morphology and physiology of these molds enable them to penetrate and colonise various solid substrates (Vijayaraghavan et al., 2011). SSF utilises various agroindustrial wastes as substrate that acts both physical support and source 
of nutrients (Pandey et al., 2001). In addition, the use of SSF for enzyme production has many advantages over submerged fermentation due to its simple technique, low capital investment, lower levels of catabolite repression and better product recovery (Considine et al., 1989). However, filamentous fungi are the best adapted for SSF. The hyphal mode of fungal growth and their good tolerance to low water activity and high osmotic pressure conditions make fungi efficient and competitive in natural microflora for bioconversion of solid substrates (Padmini et al., 2012; Pandey et al., 2001).

The objectives of the present study were, (i) to investigate the ability of Fusarium species to produce amylase, and (ii) to find out optimum condition for enzyme production under solid state fermentation.

\section{Materials and Methods}

Microorganism. Fusarium spp., isolates were obtained from wheat seeds showing disease symptoms from different locations in Syria. They were identified morphologically according to Nelson et al. (1983). Emphasis was placed on selecting isolates that induce differential reactions on specific wheat genotypes (Alazem, 2007), leading to the selection of 21 monosporic isolates (eight belonging to F. culmorum, six to $F$. verticillioides, four to $F$. solani and three to $F$. equiseti) used in this study (Table 1). The cultures were maintained on silica gel at $4{ }^{\circ} \mathrm{C}$ until needed.

Optimisation of cultural conditions. Enzyme production was carried out as reported by Bakri et al. (2008). The fermentation medium consisted of: $(\mathrm{g} / \mathrm{L})$ $\mathrm{Na}_{2} \mathrm{HPO}_{4} .2 \mathrm{H}_{2} \mathrm{O} 10 ; \mathrm{KCl} 0.5 ; \mathrm{MgSO}_{4} .7 \mathrm{H}_{2} \mathrm{O} 0.15$, and yeast extract 5 , as a nitrogen source. The influences of different lignocellulosic materials viz., wheat bran, wheat straw, corn cobs hulls, soya cake and cotton seed cake on amylase production were tested (Fig. 1). Fresh fungal spores were used as inoculum and $1 \mathrm{~mL}$ spore suspension (containing around $10^{6}$ spores $/ \mathrm{mL}$ ) was added to sterilised medium and incubated at $30{ }^{\circ} \mathrm{C}$ for 5 days. Various physical parameters such as $\mathrm{pH}$ $(4,5,6,7,8$ and 9), temperature $(20,25,30,35,40$ and $\left.45^{\circ} \mathrm{C}\right)$ and moisture level $(50,55,60,65,70,75,80$, 85 and $90 \%$ ) were optimised by conventional methods for maximal enzyme production.

Extraction of amylase. Flasks were removed after cultivation and the enzyme was extracted by adding $25 \mathrm{~mL}$ of $0.1 \mathrm{M}$ phosphate buffer ( $\mathrm{pH} 5$ ) to the cultures.
Table 1. Amylase production by Fusarium spp., in solid state fermentation

\begin{tabular}{cl}
\hline \hline Isolate & Amylase (U/g) \\
\hline F. culmorum & \\
SY1 & $45.5 \mathrm{f}$ \\
2 & $55.36 \mathrm{~d}$ \\
3 & $54.6 \mathrm{~d}$ \\
4 & $51.13 \mathrm{e}$ \\
6 & $76.13 \mathrm{~b}$ \\
12 & $52.00 \mathrm{e}$ \\
13 & $40.40 \mathrm{~g}$ \\
14 & $66.80 \mathrm{c}$ \\
F. verticillioides & \\
SY5 & $47.40 \mathrm{f}$ \\
9 & $51.40 \mathrm{e}$ \\
10 & $44.80 \mathrm{f}$ \\
15 & $54.30 \mathrm{~d}$ \\
16 & $70.95 \mathrm{bc}$ \\
17 & $39.25 \mathrm{~g}$ \\
F. solani & \\
SY7 & $118.35 \mathrm{a}$ \\
8 & $38.70 \mathrm{~g}$ \\
11 & $43.50 \mathrm{f}$ \\
20 & $41.70 \mathrm{f}$ \\
F. equiseti & \\
SY22 & \\
23 & $33.60 \mathrm{~h}$ \\
24 & $45.10 \mathrm{f}$ \\
\hline
\end{tabular}

Values within a column followed by different letters are significantly different at $\mathrm{P}<0.001$ according to Newman-Keuls test.

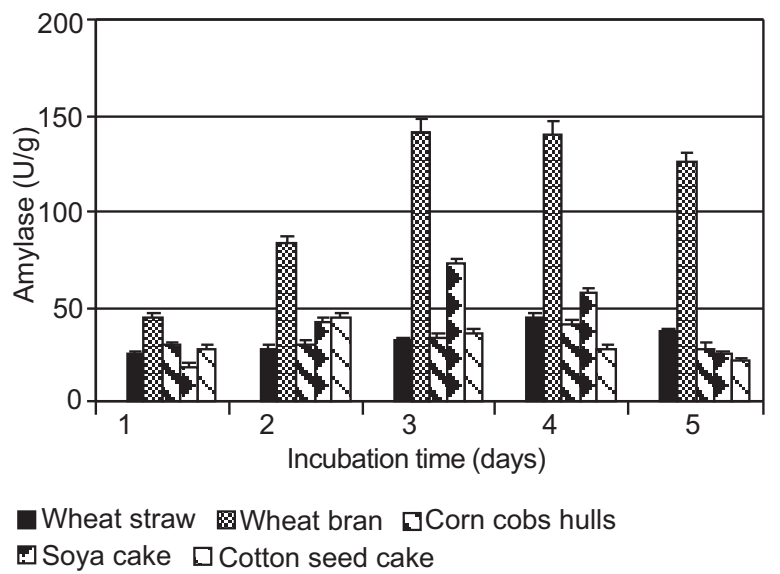

Fig. 1. Effect of lignocellulosic materials (wheat straw, wheat bran, soya cake and cotton seed cake) and incubation time on amylase production by Fusarium solani SY7. 
The mixtures were shaken for $1.5 \mathrm{~h}$ on a magnetic stirrer. The supernatant was obtained by centrifugation $(8000 \times \mathrm{g}$ for $15 \mathrm{~min})$ followed by filtration through Whatman No. 1 filter paper and the filtrate was used as a crude enzyme preparation.

Assay of amylase: $\alpha$-amylase activity was determined as described by Okolo et al. (2001). Reaction mixture contained: $1 \%$ soluble starch, $1.25 \mathrm{~mL} ; 0.1 \mathrm{M}$ acetate buffer ( $\mathrm{pH}$ 5.0), $0.25 \mathrm{~mL}$; and appropriately diluted crude enzyme extract, $0.25 \mathrm{~mL}$. After $10 \mathrm{~min}$ of incubation at $50{ }^{\circ} \mathrm{C}$, liberated reducing sugars (glucose equivalent) were estimated by the dinitrosalicylic acid method of Miller (1959). One unit (IU) of $\alpha$-amylase is defined as the amount of enzyme that releases $1 \mu \mathrm{mol}$ of glucose equivalent per min under the assay conditions and enzyme activity is expressed in terms of IU per gram dry fermented substrate.

Statistical analysis. The experiments were repeated twice and the means were analysed statistically with the analysis of variance (STAT-ICTF, 1988) with used to test for differences in amylase production among Fusarium isolates.

\section{Results and Discussion}

Amylase production from Fusarium species. The results showed that all the Fusarium species were capable of producing amylase. Significant differences $(\mathrm{P}<0.001)$ in the mean yield values were detected among isolates, with values being consistently higher in the isolates F. solani SY7 and F. culmorum SY6 (mean value 118.35 and $76.13 \mathrm{IU} / \mathrm{g}$, respectively), whereas, low enzyme activity of 33.6 and $39.25 \mathrm{IU} / \mathrm{g}$ were detected for F.equiseti SY 22 and F. verticillioides SY17, respectively (Table 1). From this collection, F. solani SY7 isolate was selected for further studies.

Influence of some wastes on amylase production by F. solani SY7. Figure 1 shows that the highest amylase production $(141.18 \mathrm{IU} / \mathrm{g})$ was obtained on wheat bran after 3 days of incubation, whereas, soya cake and cotton seed cake exhibited low amylase production. These results might be attributed to the fact that the presence of readily available substrates has been noted to influence the biosynthesis of many extracellular enzymes via catabolite repression mechanism (Vijayaraghavan et al., 2011; Teodoro and Martins, 2000). Wheat bran was found to be the best substrate for $\alpha$-amylase production by a thermophilic fungus Humicola lanuginose (Singh et al., 2009).
Influence of initial pH on amylase production by F. solani SY7. Since microorganisms are sensitive to the concentration of hydrogen ions present in the medium, $\mathrm{pH}$ is considered an important factor that determines the growth, morphology and product formation (Weiland, 1988). Figure 2 demonstrates that $\alpha$-amylase production was significant over a wide range of $\mathrm{pH}$ values and was maximum at $\mathrm{pH} 8.0$, which indicates that the selected isolate prefers alkaline conditions for better enzyme production. This was a rare occurrence because most fungal amylase required slightly acidic $\mathrm{pH}$ (4.5-6.0) (Okolo et al., 2001). Alva et al. (2007) observed two peaks optima in amylase production at initial $\mathrm{pH} 5.8$ and 9.0 by Aspergillus sp., JGI 12. On the other hand, amylase production by A. flavus isolate FSS 60 was found to be best at $\mathrm{pH} 9.0$ (Bakri et al., 2009). Thus, development of an optimal $\mathrm{pH}$ control strategy is helpful in obtaining higher enzyme productivity by the fungal strains.

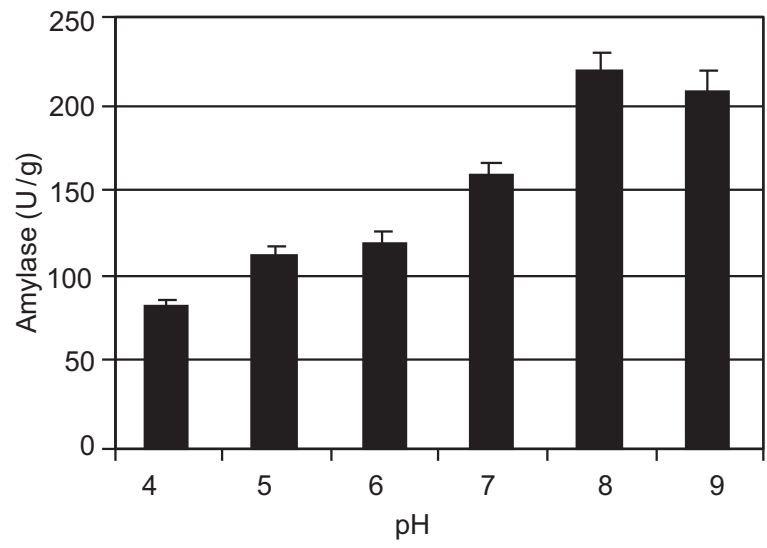

Fig. 2. Effect of pH degree on amylase produced by Fusarium solani SY7 grown on wheat bran under solid culture.

Influence of initial temperature on amylase production. Among the fungi, most amylase production studies have been conducted with mesophilic fungi within a range of temperature $\left(25-37^{\circ} \mathrm{C}\right)$ (Pandey et al., 2001). Figure 3 demonstrates the effect of temperature on $\alpha$-amylase production, where the optimum temperature for maximum $\alpha$-amylase production was $25^{\circ} \mathrm{C}$. Decrease in enzyme yield at lower or elevated temperatures resulted from the reduced metabolic activity and impaired action of the cell membrane of the fungus. The influence of temperature on the production of crude amylase showed that enzyme production decreased progressively with 
increase in temperature (Fig. 3). Above $25^{\circ} \mathrm{C}$, there was a reduction in the amylase production. It is reported that the best amylase production in A.niger is at room temperature (Varalakshmi et al., 2009) and reported $30{ }^{\circ} \mathrm{C}$ be the best for amylase production by Penicillium fellutanum and A. flavus, respectively (Hernández et al., 2006; Okolo et al., 2001).

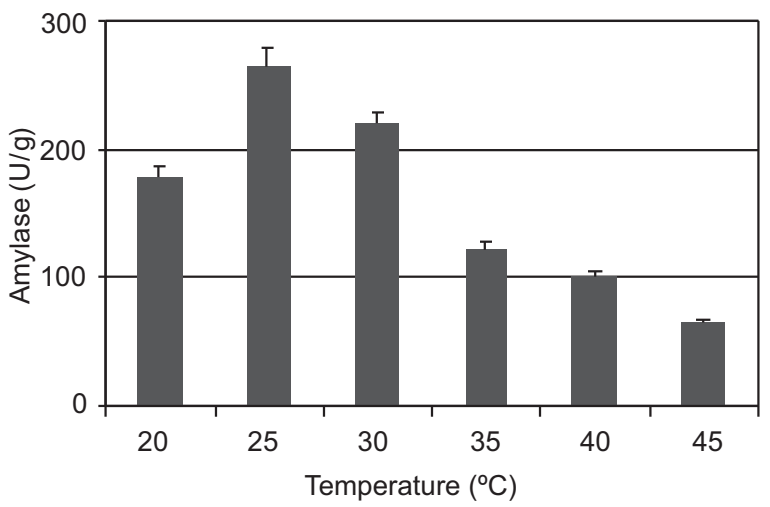

Fig. 3. Effect of temperature on amylase production by Fusarium solani SY7.

Influence of moisture level on amylase production. The results showed that the moisture level at $70 \%$ yielded the highest amylase production (Fig. 4). The critical importance of moisture level in SSF media and its influence on the biosynthesis of enzymes has been attributed to the interference of moisture in the physical properties of solid particles. Sodhi et al. (2005) reported that higher moisture level decreases porosity, changes wheat bran particle structure, promotes development

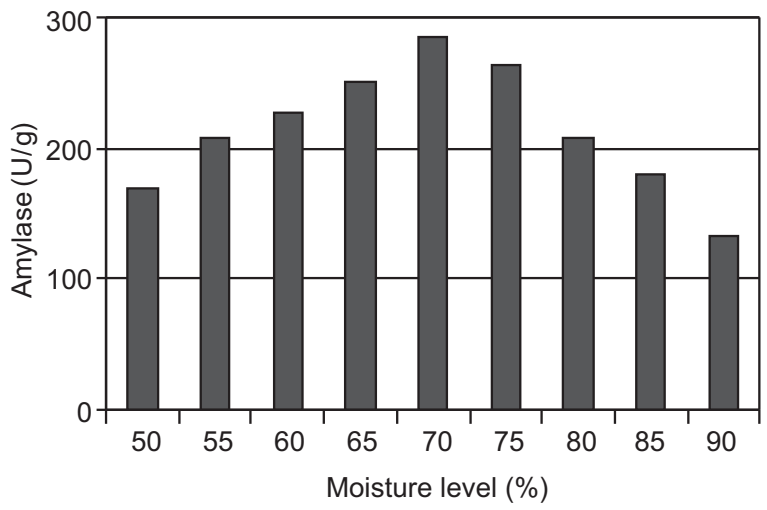

Fig. 4. Effect of moisture (\%) on amylase production by Fusarium solani SY7. of stickiness, reduces gas volume and exchange and decreases diffusion, which results in lowered oxygen transfer and reduction in enzyme production. On the other hand, lower moisture content reduces the solubility of nutrients present in solid substrate, decreases the degree of swelling and increases water tension (Ramachandran et al., 2004). Pandey et al. (1994) reported that with low water availability fungi suffer modification in their cell membranes leading to transport limitations and affecting microbial metabolism. Based on the present results, moisture at $70 \%$ seems to result in a compromise among water availability, substrate swelling and oxygen diffusion effect, favouring amylase production by F. solani SY7.

\section{Conclusion}

The present study reveals that $F$. solani $\mathrm{SY} 7$ isolate proved to be an efficient producer of $\alpha$-amylase under improved conditions. Wheat bran could be used as a less expensive substrate for efficient amylase production (141.18 U/g) after 3 days of incubation. The culture conditions can easily be modified to enhance the productivity of the enzyme formation that will facilitate the scale-up processes for biomass production.

\section{References}

Alazem, M. 2007. Characterization of Syrian Fusarium Species by Cultural Characteristics and Aggressiveness, M.Sc. Thesis, pp. 1-72, Faculty of Agriculture, University of Damascus, Syria.

Alva, S., Anumpama, J., Savla, J., Chiu, Y.Y., Vyshali, P., Shruti, M., Yogeetha, B.S., Bhavya, D., Purvi, J., Ruchi, K., Kumudini, B.S., Varalakshmi, K.N. 2007. Production and characterization of fungal amylase enzyme isolated from Aspergillus sp., JGI 12 in solid state culture. African Journal of Biotechnology, 6: 576-581.

Bakri, Y., Magali, M., Thonart, P. 2009. Isolation and identification of a new fungal strain for amylase biosynthesis. Polish Journal of Microbiology, 58: 269-273.

Bakri, Y., Jawhar, M., Arabi, M.I.E. 2008. Improvement of xylanase production by Chochliobolus sativus in solid state fermentation. Brazilian Journal of Microbiology, 39: 602-604.

Cherry, H.M., Towhid, H., Md., Anwar, M.N. 2004. Extracellular glucoamylase from the isolate Aspergillus fumigatus. Pakistan Journal of Biological Sciences, 7: 1988-1992. 
Considine, P.J., Buckley, R.J., Griffin, T.O., Tuohy, M.G., Coughlan, M.P. 1989. A simple and inexpensive method of solid-state cultivation. Biotechnology and Technology, 3: 85-90.

de Castro, R.J.S., Sato, H.H. 2013. Synergistic effects of agroindustrial wastes on simultaneous production of protease and $\alpha$-amylase under solid state fermentation using a simplex centroid mixture design. Industrial Crops and Products, 49: 813-821.

Ghasemi, Y., Rasoul-Ami, S., Ebrahimine, A., Zarrini, G., Kazemi, A., Mousavi-Khorshidi, S., Ghoshoon, M.B., Raee, M.J. 2010. Halotolerant amylase production by a novel bacterial strain, Rheinheimera aquimaris. Research Journal of Microbiology, 5: 144-149.

Guimaraes, L.H.S., Nogueira, C.S.P., Michelin, M., Rizzatti, A.C.S., Sandrim, V.C., Zanoela, F.F., Aquino, A.C.M.M., Junior, A.B., Polizeli, M.L.T.M. 2006. Screening of filamentous fungi for production of enzymes of biotechnological interest. Brazilian Journal of Microbiology, 37: 474-480.

Hernández, M.S., Rodríguez, M.R., Guerra, N.P., Rosés, R.P. 2006. Amylase production by Aspergillus niger in submerged cultivation on two wastes from food industries. Journal of Food Engineering, 73: 93-100.

Jackowiak, H., Packa, D., Wiwart, M., Perkowski, J., Busko, M., Borusiewicz, A. 2002. Scanning electron microscopy of mature wheat kernels infected with Fusarium culmorum. Journal of Applied Genetics, 43: 167-176.

Kikot, G.E., Hours, R.A., Alconada, T.M. 2010. Extracellular enzymes of Fusarium graminearum isolates. Brazilian Archives of Biology and Technology, 53: 779-783.

Miller, G.L. 1959. Use of dinitrosalicylic acid reagent for determination of reducing sugars. Analytical Chemistry, 31: 426-428.

Mishra, S., Behera, N. 2008. Amylase activity of a starch degrading bacteria isolated from soil receiving kitchen wastes. African Journal of Biotechnology, 7: 3326-3331.

Nelson, P.E., Toussoun, T.A., Marasas, W.F.O. 1983. Fusarium Species: An Illustrated Manual for Identification, The Pennsylvania State University Press, University Park, PA, USA.

Nwagu, T.N., Okolo, B.N. 2011. Extracellular amylase production of a thermotolerant Fusarium sp. isolated from Eastern Nigerian soil. Brazilian Archives of Biology and Technology, 54: 649-658.

Okolo, B.N., Ire, S., Ezeogu, L.I., Anyanwu, C.U.,
Odibo, F.J.C. 2001. Purification and some properties of a novel raw starch-digesting amylase from Aspergillus carbonarius. Journal of the Science, Food and Agriculture, 81: 329-336.

Onyika, N.B.N., Nelson, P.E. 1993. The distribution of Fusarium species in soils planted to millet and sorghum in Lesotho, Nigeria and Zimbabwe. Mycopathologia, 121: 105-114.

Padmini, D.N., Bhattacharya, S., Das, A., Rajan, S.S. 2012. Solid-state fermentation and characterization of $\alpha$-amylase from a rhizospheric isolate of Aspergillus flavus associated with Mangifera indica. Annals of Biological Research, 3: 4082-4090.

Pandey, A., Soccol, C.R., Rodriguez-Leon, J., Nigam, P. 2001. Solid State Fermentation in Biotechnology, Asiatech Publishers, Inc., 221 pp., New Delhi, India.

Pandey, A., Ashakumary, L., Selvakumar, P., Vijayalakshmi, K.S. 1994. Influence of water activity on growth and activity of $A$. niger for glucoamylase production in solid state fermentation. World Journal of Microbiology and Biotechnology, 10: 485-486.

Pekkarinen, A., Mannonen, L., Jones, B.L., NikuPaavola, M.L. 2000. Production of proteases by Fusarium species grown on barley grains and in media containing cereal proteins. Journal of Cereal Science, 31: 253-261.

Ramachandran, S., Patel, A.K., Nampoothiri, K.M., Chandran, S., Szakacs, G., Soccol, C.R., Pandey, A. 2004. Alpha amylase from a fungal culture grown on oil cakes and its properties. Brazilian Archives of Biology and Technology, 47: 309-317.

Reddy, N.S., Nimmagadda, A., Sambasiva Rao, K.R.S. 2003 . An overview of the microbial $\alpha$-amylase family. African Journal of Biotechnology, 2: 645-648.

Riaz, M., Perveen, R., Javed, M.R., Nadeem, H., Rashid, M.H. 2007. Kinetic and thermodynamic properties of novel glucoamylase from Humicola sp. Enzyme and Microbial Technology, 41: 558-564.

Singh, R.K., Kumar, S., Kumar, S. 2009. Production of $\alpha$-amylase from agricultural byproducts by Humicola lanuginosa in solid-state fermentation. Current Trends in Biotechnology and Pharmacy, 3: 172-180.

Sodhi, H.K., Sharma, K., Gupta, J.K., Soni, S.K. 2005. Production of a thermostable $\alpha$-amylase from Bacillus sp. PS-7 by solid state fermentation and its synergistic use in the hydrolysis of malt starch for alcohol production. Process Biochemistry, 40: 525-534.

STAT-ITCF, 1988. Manuel d'utilisation, Institute 
Techniques des Cereales et des Fourrages 210 pp., Services des Etudes Statistiques, Boiyneville, France.

Summerell, B.A., Leslie, J.F., Backhouse, D., Bryden, W.L., Burgess, L.W. 2001. Fusarium: Paul E. Nelson Memorial Symposium, 388 pp., $1^{\text {st }}$ edition, American Phytopathological Society Press, St. Paul Minnesota, USA.

Teodoro, C.E.D., Martins, M.L.L. 2000. Culture conditions for the production of thermostable amylase by Bacillus sp. Brazilian Journal of Microbiology, 31: 298-302.

Varalakshmi, K.N., Kumudini, B.S., Nandini, B.N., Solomon, J., Suhas, R., Mahesh, B., Kavitha, A.P. 2009. Production and characterization of alpha amylase from Aspergillus niger JGI 24 isolated in Bangalore. Polish Journal of Microbiology,
58: 29-36.

Vijayaraghavan, P., Remya, C.S., Prakash, Vincent, S.G. 2011. Production of $\alpha$-amylase by Rhizopus microsporous using agricultural by-product in solid state fermentation. Research Journal of Microbiology, 6: 366-375.

Weiland, P. 1988. Principles of solid state fermentation. In: Treatment of Lignocellulosics with White Rot Fungi, F. Zadrazil and R. Reiniger (eds.), pp. 6466, Elsevier Applied Science, London, UK.

Zaferanloo, B., Bhattacharjee, S., Ghorbani, M.M., Mahon, P.J., Palombo, E.A. 2014. Amylase production by Preussia minima, a fungus of endophytic origin: optimization of fermentation conditions and analysis of fungal secretome by LC-MS. BMC Microbiology, 14: 55. http://www.biomedcentral.com/1471-2180/ $14 / 15$ 